\section{AUTHORS:}

Walter Cristiano ${ }^{1,2}$

Cristina Giacoma ${ }^{2}$

Mario Carere ${ }^{1}$

Laura Mancini $^{1}$

\section{AFFILIATIONS:}

Unit of Ecosystems and Health, Department of Environment and Health, Italian National Institute of Health, Rome, Italy

2Department of Life Sciences and Systems Biology, University of Turin, Turin, Italy

\section{CORRESPONDENCE TO:}

Walter Cristiano

\section{EMAIL:}

walter.cristiano@guest.iss.it walter.cristiano@unito.it

DATES:

Received: 15 Feb. 2021

Revised: 25 May 2021

Accepted: 08 June 2021

Published: 29 Sep. 2021

\section{HOW TO CITE:}

Cristiano W, Giacoma C, Carere

M, Mancini L. Chemical pollution

as a driver of biodiversity loss and

potential deterioration of ecosystem

services in Eastern Africa: A critical

review. S Afr J Sci. 2021;117(9/10)

Art. \#9541. https://doi.

org/10.17159/sajs.2021/9541

\section{ARTICLE INCLUDES:}

囚 Peer review

$\square$ Supplementary material

DATA AVAILABILITY:

$\square$ Open data set

$\square$ All data included

$\square$ On request from author(s)

$\square$ Not available

凶 Not applicable

EDITORS:

Jennifer Fitchett iD

Yali Woyessa (iD

\section{KEYWORDS:}

chemical pollution, biodiversity loss ecosystem services, African wildlife ecosystem health

\section{FUNDING:}

None

\title{
Chemical pollution as a driver of biodiversity loss and potential deterioration of ecosystem services in Eastern Africa: A critical review
}

\begin{abstract}
Chemical pollution, i.e. the release of anthropogenic chemical substances into the environment, is a driver of biodiversity loss. Although this issue has been widely investigated in high-income countries of temperate regions, there is a lack of data for tropical areas of middle- or low-income countries, such as those in Eastern Africa. Some of the world's richest biomes that are affected by multiple pressures, including chemical pollution, are hosted in this macro-region. However, few studies have addressed the impact of the release of anthropogenic chemical pollutants on the biodiversity, and the related potential implications for the deterioration of ecosystem goods and services in this area. A contribution in systemising the scientific literature related to this topic is, therefore, urgently needed. We reviewed studies published from 2001 to 2021, focusing on the chemical pollution impact on Eastern African wildlife. Despite an extensive literature search, we found only 43 papers according to our survey methods. We focused on wildlife inhabiting terrestrial ecosystems and inland waters. According to our search, Kenya and Uganda are the most represented countries accounting for about half of the total number of reviewed articles. Moreover, $67.4 \%$ of the studies focus on inland waters. The spread of anthropogenic chemicals into tropical areas, e.g. Eastern Africa, and their effects on living organisms deserve greater attention in research and politics. We report a weak increasing trend in publishing studies addressing this topic that might bode well. The combined effort of science and governments is crucial in improving the management of chemical pollutants in the environment for achieving the goals of biodiversity conservation.
\end{abstract}

\section{Significance:}

- $\quad$ Chemical pollution represents an underestimated risk for the health of tropical ecosystems in middle- and low-income countries, such as those of Eastern Africa.

- There is a lack of data on chemical pollution effects on wildlife of Eastern African biomes.

- The anthropogenic release of chemical substances affects the health of biodiversity and humans, negatively influences ecosystem services in Eastern Africa, and makes conservation and protection measures less effective.

- There is an urgent need for improving research on chemical pollution effects and promoting a sustainable use of natural resources in Eastern Africa along with better management of farming and mining activities.

\section{Introduction}

Biodiversity loss is a global environmental issue. The rate of species extinction has been dramatically increasing over the last few decades. ${ }^{1-3}$ This is mainly due to climate change ${ }^{4}$ and many anthropogenic pressures that ecosystems face ${ }^{5}$. Amongst these threats, the release and the discharge of chemical pollutants into the environment, i.e. chemical pollution, is a major concern for the health and survival of living organisms, such as plants and animals, including humans. ${ }^{6,7}$ Furthermore, such pressure directly affects biodiversity and human health through biomagnification in the food chain. ${ }^{8}$ Human well-being is likely to be impaired in a roundabout way on account of ecosystem service damage due to biodiversity loss. ${ }^{9,10}$ Ecosystem services represent the benefits provided by nature to humanity, including food, pure water, pharmaceuticals, climate regulation, pollination and pest control, defence against natural hazards, and reduction of infectious diseases. ${ }^{9,10}$ For instance, wildlife habitat exploitation and hunting may facilitate the spread of zoonosis. ${ }^{9}$ At the same time, anthropogenic pressures such as chemical pollution could lead to loss of biodiversity, and there is evidence that such events might have an adverse impact on basic ecosystem services, e.g. primary production and nutrient recycling, and final ecosystem services, e.g. food and water supply. ${ }^{7}$ Therefore, it follows that biodiversity loss and ecosystem services are closely related, and have the potential to affect both human health and global economies. ${ }^{10}$

Because the spread of chemical pollutants in the environment represents a serious concern for ecosystem health ${ }^{11}$, holistic approaches such as One Health and Eco-Health have emerged in the last few years. Both these approaches assume that humans, animals, and the ecosystems to which they belong interact in a complex way and at different levels. According to these concepts, the environment, humans, and other animals can affect each other, so protecting ecosystems means protecting ourselves. ${ }^{12}$ High-income countries located in temperate areas have adopted measures to mitigate and prevent the release of hazardous chemical substances. For instance, according to the Water Framework Directive, European Union member states are obliged to achieve a good chemical quality status for all their water bodies by including a list of priority chemical pollutants that must be monitored in water, sediment or biota. ${ }^{13}$ Unlike temperate ecosystems, where the chemical pollution effects on biodiversity have been widely investigated for decades, only a few studies have addressed the effects of such environmental contamination in tropical areas. These territories often lie in low- and middle-income countries (according to 
the classification provided by the United Nations ${ }^{14}$ ), and host global biodiversity hotspots ${ }^{15,16}$. In tropics, large forests are the dwelling of most of the terrestrial species worldwide in terms of diversity. ${ }^{17}$ These ecosystems face the challenges of deforestation and overexploitation of natural resources, which are involved in tropical biodiversity loss together with climate change and invasive species introduction. ${ }^{18}$ Agriculture and mining complicate this picture by representing the main drivers of chemical pollution of water and soil. Such activities involve the release of ubiquitous environmental chemical pollutants such as organochlorine compounds (OCs) and heavy metals. ${ }^{11,19}$ It follows that chemical pollution is a global emergency concerning the health of all the different ecosystem components, i.e. environment, animals, humans. This is particularly evident in middle- and low-income countries, where the effects of the release of chemical pollutants into the environment are particularly acute. For instance, more than $90 \%$ of world pollutionrelated deaths in children occur in such world regions. ${ }^{20}$ In these areas, the adverse effects of climate change may also increase the impacts of anthropogenic pressures on the ecosystem, including chemical pollution. ${ }^{21,22}$ This is a worrying scenario because the interactive effect of climate change and the release of chemical pollutants into the environment is rather unknown. ${ }^{23}$ Furthermore, the already limited resources and infrastructures of tropical countries may collapse under the burden of environmental hazards exacerbated by climate change. ${ }^{24}$ Therefore, further research is needed to address chemical pollution effects in tropical areas of middle- and low-income countries.

Our work aimed to help to systematise the scientific literature on chemical pollution threats, i.e. the release and discharge of anthropogenic contaminants to wildlife in tropical areas, and to provide a benchmark for future precautionary environmental actions. We chose the ecosystems of the eastern African macro-region as a case study because they represent some of the most important world biomes and they are located in tropical middle- and low-income countries. ${ }^{25}$ Promoting the need for improving research on the effects of chemical pollution on African tropical ecosystems as a driver for biodiversity loss and ecosystem service degradation is the goal of our review in a wider perspective. Particularly, we focus on the wildlife of inland waters and terrestrial ecosystems, and we discuss potential implications for human health.

\section{Survey method}

We summarised the current state of affairs on the effects of anthropogenic chemical pollution on the health of wildlife (i.e. wild vertebrate and invertebrate species) of Eastern African ecosystems. We considered studies that analysed the direct or indirect impacts of chemicals on animal biota. Furthermore, only studies published in English were considered. According to the United Nations classification, there are 18 countries within the Eastern Africa macro-region, excluding the French and British overseas territories (Figure 1) ${ }^{14}$ All of these countries are classified as middle- or low-income countries. ${ }^{26}$ The discussion is divided into subsections on geographical, social, and political subregion-specific characteristics.

We collated scientific articles published in accredited journals from 2001 to early 2021 (until the time of submission of this paper) indexed in PubMed, Scopus or Web of Science (all databases) that focused on the environmental contamination of inland waters and terrestrial ecosystems. For our search, we used the country name AND "chemical pollution" AND one of the following keywords at a time: "wildlife", "biodiversity", "ecosystem services". We repeated the query including each of the keywords for each country of Eastern Africa. We then used the country name AND "environmental pollution" and each of the aforementioned keywords and countries. The survey was conducted by searching titles, keywords, and abstracts. We manually checked each result obtained by typing the chosen keywords in combination with the country name and "chemical pollution/environmental contamination" terms, and we included in our review any relevant results, i.e. all the contributions that addressed the topic of our interest in a country of Eastern Africa, and excluded those results not relevant to our topic.

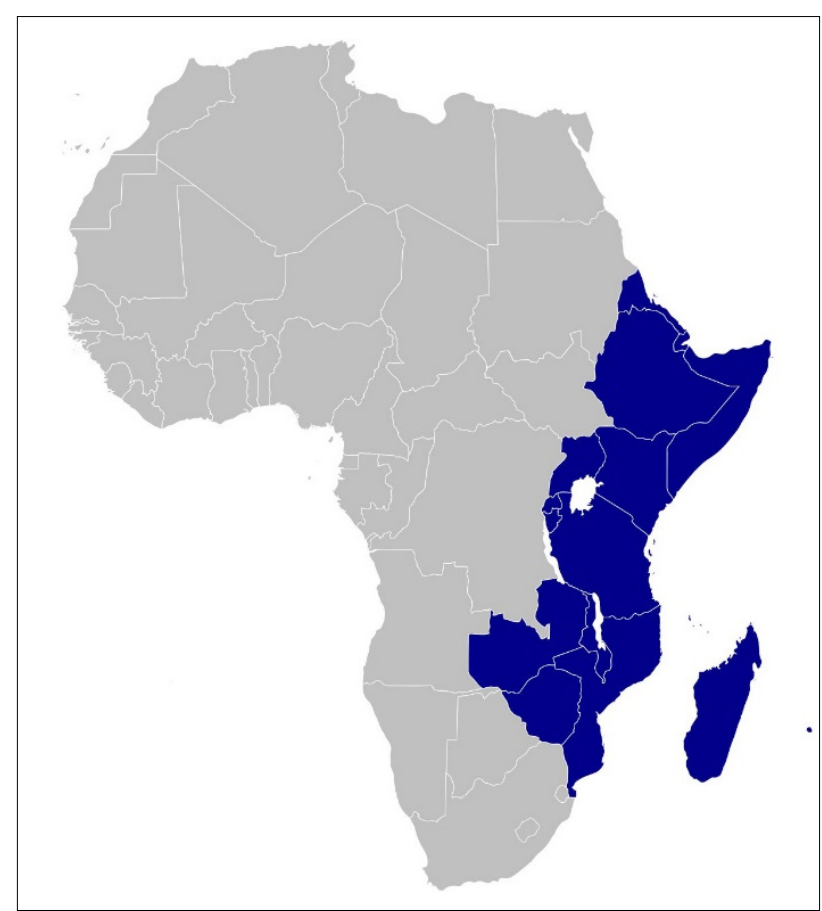

Image: Sannita/Wikimedia Commons/CC-BY-SA-3.0

Figure 1: Map of the African continent. The countries shaded in blue comprise the Eastern Africa macro-region as designated by the United Nations (Statistic Division, Department of Economic and Social Affairs).

We then counted the published articles per year and ran a regression analysis with the aim of identifying potential trends in publishing over time. We did not include the 2021 publications because data for this year are not comparable as a full year was not possible. The regression model was built by setting the year of publication as the predictor variable and the number of articles per year as the dependent variable. The analysis was run in $\mathrm{R}$ version 4.0.4. Finally, we calculated the percentages of published articles related to terrestrial and water ecosystems, and the percentage related to each country.

A few references that we found addressed both the direct effects of such pollution sources on biodiversity and the indirect implications for human health and well-being. We discuss and stress such interactions. Due to the limited number of studies, not all the countries within the United Nations classification of Eastern Africa were represented in the search results.

\section{Results and discussions}

Eastern Africa is home to some of the most endangered ecosystems on earth, including different biomes ${ }^{27}$ such as steppes, savannahs and rainforests. Information on the effects of chemical pollution on subSaharan ecosystems is very limited. ${ }^{15,28}$ The scarce financial resources due to disadvantaged economies and the simultaneous presence of several emergencies, e.g. political conflicts ${ }^{29}$, make it difficult to implement monitoring strategies aimed at investigating the potential risks of environmental pollution on ecosystem health. Furthermore, legislation on chemical pollution is lacking. ${ }^{30}$

Despite an extensive literature search, we found only 43 published articles covering the direct effects of chemical pollution on animals. All the articles retrieved were published between 2001 and January 2021. According to the reviewed studies, the main risks associated with chemical pollution on wildlife are attributed to persistent organic pollutants, especially OCs and heavy metals. OCs are highly persistent in the environment. Exposure to OCs affects living organisms in different ways, including neurotoxic, immunotoxic, cardiotoxic, genotoxic, reproductive, and developmental effects. Furthermore, some OCs cause cancer in different mammals. ${ }^{31}$ As for OCs, heavy metals show high 
persistence in the environment and negatively affect living organisms. Such chemical pollutants often occur in the environment as a cocktail of substances whose effects on ecosystems are unknown. ${ }^{32}$ However, heavy metal exposure leads to oxidation stress, which may induce several adverse effects such as DNA damage and protein modification. ${ }^{33}$ There is a close and complex relationship between chemical pollution, biodiversity and human health, and the deterioration of ecosystem services. ${ }^{7}$

We found a slight increasing trend in published studies on chemical pollution and wildlife among countries of Eastern Africa (Figure 2). Although quite weak, the trend is statistically significant. Regression analysis returned a $p$-value equal to 0.03348 . Kenya and Uganda were the most represented countries according to our search methods, together accounting for almost half of the retrieved studies, i.e. 20 of 43 articles (Table 1). No data are reported for South Sudan, Eritrea, Djibouti, Malawi, Mozambique, Comoros, Mauritius, and the Seychelles because we did not find a study for these countries through our search. Most of the studies were carried out in inland waters (67.4\%). Terrestrial ecosystems accounted for $23.3 \%$, and only $9.3 \%$ of the analysed studies involved both aquatic and land ecosystems (Figure 3 ).

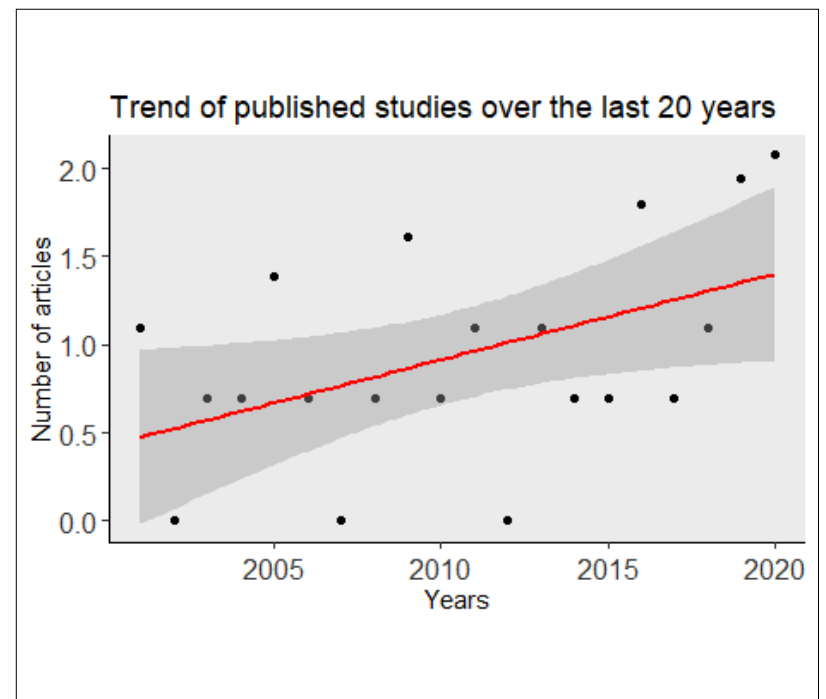

Figure 2: Trend of publications on the chemical pollution effects on the biota of Eastern Africa during the last 20 years.

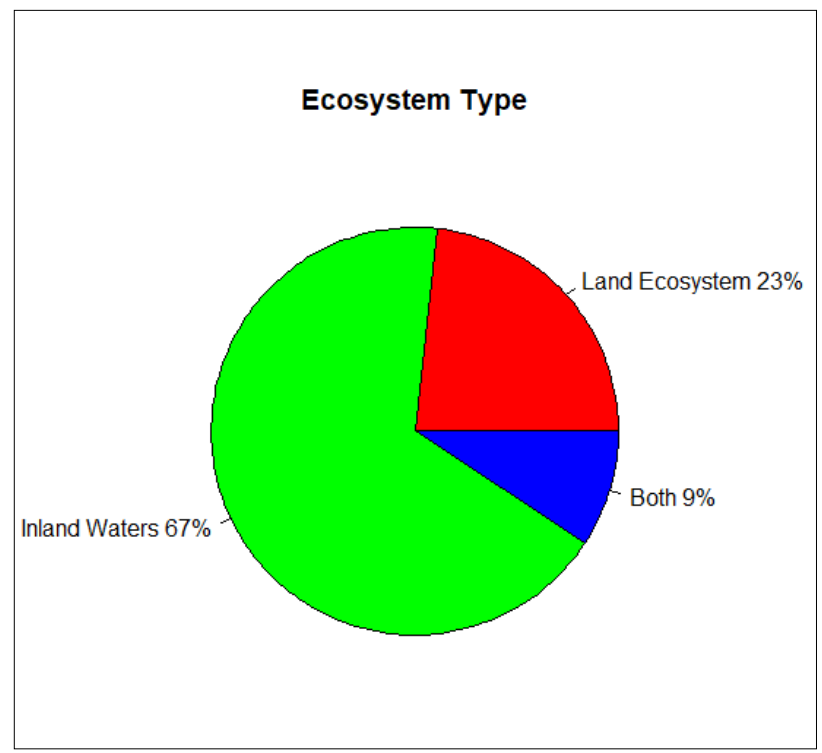

Figure 3: Percentage of articles reviewed according to the target ecosystem investigated.
Table 1: Number of articles retrieved by country in the timespan 20012021

\begin{tabular}{l|c}
\hline \hline \multicolumn{1}{c|}{ Country } & Number of published studies \\
\hline Burundi & 1 \\
\hline Ethiopia & 4 \\
\hline Kenya & 10 \\
\hline Madagascar & 3 \\
\hline Rwanda & 1 \\
\hline Tanzania & 7 \\
\hline Uganda & 10 \\
\hline Zambia & 8 \\
\hline Zimbabwe & 3 \\
\hline
\end{tabular}

\section{Horn of Africa}

There are a lack of data for the countries of the Horn of Africa (i.e. Ethiopia, Eritrea, Somalia and Djibouti), although, more recently, a few studies have addressed the effects of effluents on the ecological health of different Ethiopian water basins by assessing macro-invertebrate abundance and diversity. All these investigations found an inverse correlation between water quality and the presence of macro-invertebrates. ${ }^{34-37}$

\section{East African Community}

Countries of Eastern Africa that share geographical elements and common interests constitute the East African Community. A batch of studies has addressed the impact of chemical pollution in this area, especially in freshwater ecosystems. In 2019/2020, Musonge et al. ${ }^{38,39}$ developed macro-invertebrate-based indexes to investigate the chemical pollution patterns in a biodiversity hotspot in Uganda, the Rwenzori region. Their studies found evidence of pollution according to the different abundances of the macro-invertebrates compared to reference sites. Vertebrate species, such as amphibians, also seem to be sensitive to chemical pollution. In a recent study, in vivo bioassays on a nontarget organism, Xenopus levis tadpoles, revealed endocrinological, developmental, and behavioural effects due to exposure to water in the Kibale National Park, where 13 pesticides, e.g. carbofuran and 2.4-D amine, were detected. These results indicate a potential health risk for wildlife and humans living in the area. ${ }^{40}$

In the context of freshwater ecosystems, major attention has been placed on Lake Victoria. Bordered by Kenya, Tanzania, and Uganda, this water basin is the largest tropical lake in the world. The environmental chemical contamination of this reservoir is a threat for millions of people living in the surrounding area. The pollution of Lake Victoria also has implications for the economy of the local communities that depend on the exploitation of the water basin for fishing. Therefore, the assessment of environmental pollutants in fish of Lake Victoria is a challenge. At least two studies in Uganda tried to address this issue by studying the impact of pollution on animals inhabiting this ecosystem. In 2019, Badamasi et al. ${ }^{41}$ detected biochemical and morphological alterations in three fish species of commercial interest living in this water basin: Oreochromis niloticus, Lates niloticus, and Protopterus aethiopicus. Already in 2006, Focardi et al. ${ }^{42}$ reported concentrations of mercury above the limits outlined by the World Health Organization (WHO) in the tissues of common fish species sampled in the Ugandan side of the lake. Evidence of pollution was also found by investigating the impact of agricultural activities on dragonflies. The order Odonata is vulnerable to pesticide use, particularly at the larval stage. In 2009, Martins ${ }^{43}$ observed significant differences in the abundance and diversity of dragonflies between pesticide-fished areas and protected areas within the lake. Only a couple of species were found in the impacted areas compared to more than 20 species living in the protected ones. 
The pattern of chemical pollution was investigated in Tanzania in four different lakes, including Lake Victoria and Lake Tanganyika. High levels of persistent organic pollutants were assessed in the tissues of fish belonging to the genus Tilapia. ${ }^{44}$ Such environmental contamination might have direct impacts on human health because these fish represent an important food source for the increasing country population. Lake Tanganyika is also affected by heavy metal contamination. Analyses on fish species, including two important market fish, Lates microlepis and Clarias theodorae, indicated mercury biomagnification in the tissues exceeding the limit of $0.2 \mu \mathrm{g} \mathrm{Hg} / \mathrm{g}$ established by the WHO for vulnerable populations with a high rate of fish consumptions. ${ }^{45}$ Mercury biomagnification was also found in Lake Nabugabo, Uganda, by Hanna et al. ${ }^{46}$ Different tissues of the Nile perch (Lates niloticus) showed mercury contamination, although the reported concentrations were below the value of $0.5 \mu \mathrm{g} / \mathrm{g}$ set by the guidelines of WHO and the Food and Agriculture Organization of the United Nations. ${ }^{46}$

Studies on the water quality of Lake Victoria were also performed in Kenya. Farming activities were suggested as the main drivers for loss of aquatic macro-invertebrates because of pesticide release. Different streams are affected by such disturbance, and this is reflected in the diversity and abundance of many macro-invertebrate species. ${ }^{47-50} \mathrm{~A}$ decreasing gradient of macro-invertebrate richness and diversity was also detected in the Kilombero Valley in Tanzania. This area is a wetland whose streams flowing into the area are commonly used for irrigation. This practice is associated with the degradation of the water quality because of chemical pollutant run-off and leaching. ${ }^{51}$ Pesticides may also represent a serious threat to human health, especially via food consumption. Based on the results obtained by investigating the aquatic environment near Morogoro, Groffen et al..$^{52}$ have recently pointed out the risk to human health from eating shrimp and fish daily. Indeed, according to the quality guidelines and standard values, exceeding concentrations of heavy metals and persistent organic pollutants including copper, zinc, and perfluorooctanesulfonic acid - have been found in both invertebrate and vertebrate aquatic species. ${ }^{52}$ Mdegela et al. ${ }^{53}$ reported evidence of environmental contamination in sewage effluents in Morogoro by using the wild African sharptooth fish (Clarias gariepinus) as a model, but only heavy metals were detected. In 2016, Omwenga et al. ${ }^{54}$ assessed the impact of pesticides on Oreochromis niloticus, a fish commonly used in aquaculture and reared in Kiambu and Machakos Counties, Kenya. They found evidence of different pesticide traces, including dichlorodiphenyltrichloroethane (DDT), i.e. a chemical widely used in sub-Saharan Africa until recent times, on many target fish organs. Nevertheless, the levels of contamination were lower in all the fish sampled than the limits defined by the Food and Agriculture Organization. ${ }^{54}$ Exposure to pesticides also has negative implications for birds and mammals. Otieno et al. found evidence of wildlife poisoning due to the overuse of carbofuran ${ }^{55,56}$, one of the most toxic carbamate pesticides. By using forensic analyses, they observed that carbofuran and its metabolites were implicated in the poisoning of Gyps africanus, an African vulture species. ${ }^{5,56}$ Recent findings also showed potential diet-related health risks for a critically endangered primate species, the mountain gorilla (Gorilla beringei) living in the Bwindi Impenetrable National Park located in the southwest of Uganda, that feeds on leaves containing concerning DDT levels. ${ }^{57}$ Little is known about the exposure to anthropogenic chemical substances of many other primates that face the risk of extinction. In the forests of Uganda, where land expansion critically exposes animals to different pesticides, the impact of cypermethrin, glyphosate, and chlorpyrifos, was assessed in wild chimpanzees (Pan troglodytes) and baboons (Papio anubis). By acting as endocrine disruptors, such pesticides lead to severe health defects, including facial dysplasia. ${ }^{58,59}$ Wang et al. ${ }^{60}$ also recently revealed the presence of different pesticides and flame retardants in faecal samples of wild chimpanzees, baboons, red-tailed monkeys (Cercopithecus ascanius), and red colobuses (Piliocolobus tephrosceles).

Furthermore, a study led by Buhungu et al. ${ }^{61}$ in Burundi estimated the ecological status of the Kinyankonge River by applying a Biotic Integrity Index to study the zooplankton communities. The results outlined a degradation of the ecological quality, particularly in the upstream sampling stations. ${ }^{61}$ Chemical pollution might also be involved in the micro-evolutionary processes of water organisms. For instance, in 2020, it was suggested by Gomes-Silva et al. ${ }^{62}$ that the fitness of invasive wild guppies (Poecilia reticulata) living in a river basin of Rwanda may be impaired by local water pollution.

\section{Southeast African countries}

Mining activity represents a major threat to the ecosystem health of the Kafue River in Zambia. Syakalima et al. ${ }^{63,64}$ reported heavy metal traces, such as copper, zinc, manganese and lead, in samples collected from different fish species and the Kafue lechwe antelope (Kobus leche kafuensi) living in the area. Heavy metal concentrations were also found in liver and kidney samples collected from crocodiles (Crocodylus niloticus) inhabiting the Kafue River and another Zambian water basin, the Luangwa River. ${ }^{65}$ Traces of various pesticides were also detected in the adipose tissue of hippopotami (Hippopotamus amphibius) sampled from the Luangwa River. ${ }^{66}$ Mining sites were suggested as drivers of bioaccumulation of lead, zinc, copper, cadmium, and cobalt in mammals, as indicated by the analyses carried out in Zambia on the organs of two wild black rat species (Rattus rattus and Rattus tanezumi). Such exposure to heavy metals involves alterations in gene expression. ${ }^{67,68}$ Other studies in the Zambian city of Kabwe showed heavy metal contamination in the muscular system of fish belonging to the Serranochromis genus ${ }^{69}$, and in liver, lung, stomach, and blood samples obtained from local lizards (Trachylepis wahlbergii) $^{70}$.

There are very little data accounting for the neighbouring southeast African countries. Impact on macro-invertebrate abundance and diversity was observed in the riverine systems of Bulawayo, Zimbabwe, and these results confirmed the sensitivity of such organisms to urban pollution. ${ }^{71,72}$ Similar approaches were applied by Bere et al. ${ }^{73}$ in the Manyame River system with the aim of investigating the impact of heavy metals on the ecological health of this site.

\section{African countries in the Indian Ocean}

The island of Madagascar is one of the hottest biodiversity hotspots worldwide and hosts a huge number of species, most of them endemic. ${ }^{74}$ The International Union for the Conservation of Nature (IUCN) classifies as endangered or critically endangered a large part of the wildlife of Madagascar, including almost all lemur species..$^{75}$ The ring-tailed lemur (Lemur catta), one of the flagship species of Madagascar, is affected by at least two classes of persistent organic pollutants, i.e. OCs and heavy metals. Different levels of OCs and metals were found in the blood and hair of wild lemurs. ${ }^{76}$ The exposure to persistent organic pollutants represents a concern also for another lemur species, the indri (Indri indri). Indris living in disturbed forested areas showed higher levels of nickel and cobalt in their serum compared with those living in the pristine forest, ${ }^{77}$ although the effects of such metal exposure on the health of this species have still to be fully understood. However, whereas the number of wild indri populations is decreasing, these findings that show a certain level of chemical pressure on the species must be taken into account as they might be important in terms of conservation, especially from a long-term perspective. The hazards of chemical pollution to the wildlife of Madagascar also arise from the use of insecticides, such as Fipronil (class of phenylprazole insecticides), to fight the locust plague to which the country is frequently subjected. Evidence of food chain perturbations due to the control of locusts in termite colonies and their vertebrate predators has been reported. ${ }^{78}$

\section{Final remarks and conclusions}

We have presented an overview of published studies on chemical pollution effects on wildlife diversity in Eastern African tropical areas, underlying the indirect effects for human health and ecosystem service impairment. Environmental protection and biodiversity conservation are prerequisites for maintaining good-quality services and benefits provided by ecosystems over time. The evidence that we found in our review, albeit scant, seems to indicate that such equilibrium in many Eastern African countries is potentially affected by chemical pollution. Our outputs may indicate a potential underestimated risk for the wildlife of Eastern Africa, including several critically endangered species. Despite the weak increasing number of studies, research addressing 
these issues is still dramatically lacking. Such a knowledge gap may spoil the efforts in biodiversity conservation, and thereby compromise the ecosystem health overall. Indeed, the reduction in biodiversity is likely to impair ecosystem services, which could reduce resources and exacerbate social unrest in middle- and low-income countries.

Understanding and evaluating the effects of chemical pollution on tropical biodiversity and their associated impact on ecosystem services is a challenge. ${ }^{7}$ The lack of evidence on this topic in the scientific literature demonstrates the urgent need for an international vision for sub-Saharan environmental studies. Indeed, this scenario strongly affects the chances to address chemical pollution impairment to biodiversity and ecosystem services in these tropical areas, and implement successful environmental protection strategies aimed at preserving the health of African ecosystems as a whole, including humans. A chemical pollution assessment should become an asset in the political programmes of Eastern African states. The establishment of monitoring strategies for priority pollutants, on the basis of the European Union's Water Framework Directive approach ${ }^{13}$, could address the application of fit-forpurpose preventive measures in order to protect the ecosystems and to promote human health and safety.

In some countries, such as Uganda and Madagascar, progress is ongoing. The role of the Ugandan Environmental Health Practitioners has been indicated as fundamental in applying the One Health vision to environmental management. Environmental Health Practitioners promote public health by applying the One Health approach to the monitoring of several environmental features, including chemical substances. ${ }^{79}$ Similarly, the identification and assessment of chemical pollution has been defined as a priority issue according to the National Health and Pollution Action Plan of Madagascar. ${ }^{80}$ These long-term goals represent suitable strategies for developing and implementing solutions to environmental challenges in Eastern Africa. Only a global research effort may meet such goals, and the involvement of different actors, e.g. research institutes, governments and local communities, in achieving these ambitious goals is fundamental. Therefore, high-income countries are being called upon to play their part together with the middle- and low-income countries in overcoming this challenge.

\section{Competing interests}

We have no competing interests to declare.

\section{Authors' contributions}

W.C.: Conceptualisation, methodology, data collection, data analysis, writing - the initial draft, writing - revisions. C.G.: Validation, student supervision, project leadership. M.C.: Methodology, validation, writing - revisions. L.M.: Conceptualisation, validation, student supervision, project leadership.

\section{References}

1. Wake DB, Vredenburg VT. Are we in the midst of the sixth mass extinction? A view from the world of amphibians. Proc Natl Acad Sci USA. 2008;105(1):11466-11473. https://doi.org/10.1073pnas.0801921105

2. Butchart SHM, Walpole M, Collen B, Van Strien A, Scharlemann JPW, Almond REA, et al. Global biodiversity: Indicators of recent declines. Science. 2010;328(5982):1164-1168. https://doi.org/10.1126/science.1187512

3. Ceballos G, Ehrlich PR, Barnosky AD, García A, Pringle RM, Palmer TM. Accelerated modern human-induced species losses: Entering the sixth mass extinction. Sci Adv. 2015;1(5):1-5. https://doi.org/10.1126/sciadv.1400253

4. Soroye P, Newblod T, Kerr J. Climate change contributes to widespread declines among bumble bees across continents. Science. 2020;367(6478):685-688. https://doi.org/10.1126/science.aax8591

5. Vanbergen AJ. Threats to an ecosystem service: Pressures on pollinators. Front Ecol Environ. 2013;11(5):251-259. https://doi.org/10.1890/120126

6. Backhaus T, Snape J, Lazorchak J. The impact of chemical pollution on biodiversity and ecosystem services: The need for an improved understanding. Integr Environ Assess Manag. 2012;8(4):575-576. https://doi.org/10.1002/ ie am. 1353
7. Noyes PD, Lema SC. Forecasting the impacts of chemical pollution and climate change interactions on the health of wildlife. Curr Zool. 2015;61(4):669-689. https://doi.org/10.1093/czoolo/61.4.669

8. Fu L, Lu X, Niu K, Tan J, Chen J. Bioaccumulation and human health implications of essential and toxic metals in freshwater products of Northeast China. Sci Total Environ. 2019;673:768-776. https://doi.org/10.1016/j. scitotenv.2019.04.099

9. Myers SS, Gaffikin L, Golden CD, Ostfeld RS, Redford KH, Ricketts TH, et al. Human health impacts of ecosystem alteration. Proc Natl Acad Sci USA. 2013;110(47):18753-18760. https://doi.org/10.1073/pnas.1218656110

10. IPBES Global assessment report on biodiversity and ecosystem services. Summary for policymakers of the global assessment report on biodiversity and ecosystem services of the Intergovernmental Science-Policy Platform on Biodiversity and Ecosystem Services [document on the Internet]. c2019 [cited 2021 Feb 15]. Available from: https://www.ipbes.net/sites/default/files/ downloads/spm_unedited_advance_for_posting_htn.pdf

11. Bayen S, Segovia Estrada E, Zhang H, Lee WK, Juhel G, Smedes F, et al. Partitioning and bioaccumulation of legacy and emerging hydrophobic organic chemicals in mangrove ecosystems. Environ Sci Technol. 2019;53:2549 2558. http://dx.doi.org/10.1021/acs.est.8b06122

12. Harrison S, Kivuti-Bitok L, Macmillan A, Priest P. EcoHealth and One Health: A theory-focused review in response to calls for convergence. Environ Int. 2019;132, Art. \#105058. https://doi.org/10.1016/j.envint.2019.105058

13. European Commission. Directive 2000/60/EC of the European Parliament and of the Council, 08 12, Official Journal (OJ L 226) [webpage on the Internet]. c2013 [cited 2021 Feb 15]. Available from: https://eur-lex.europa.eu/eli/ dir/2013/39/oj

14. United Nations. Country classification [document on the Internet]. c2014 [cited 2021 Feb 15]. Available from: https://www.un.org/en/development/ desa/policy/wesp/wesp_current/2014wesp_country_classification.pdf

15. Weiss FT, Leuzinger M, Zurbrügg C, Eggen RIL. Chemical pollution in low- and middle-income countries. Zürich: Swiss Federal Institute of Aquatic Science and Technology; 2016. Available from: https://www.eawag.ch/fileadmin/ Domain1/Abteilungen/sandec/publikationen/Chemical Pollution/LamicsWEB.pdf

16. Gunnarsson JS, Castillo LE. Ecotoxicology in tropical regions. Environ Sci Poll Res. 2018;25:13203-13206. https://doi.org/10.1007/s11356-018-1887-4

17. Giam X. Global biodiversity loss from tropical deforestation. Proc Natl Acad Sci USA. 2017;114(23):5775-5777. https://doi.org/10.1073/pnas.1706264114

18. Morris RJ. Anthropogenic impacts on tropical forest biodiversity: A network structure and ecosystem functioning perspective. Phil Trans Roy Soc B. 2010;365:3709-3718. https://doi.org/10.1098/rstb.2010.0273

19. Tornero V, Sylvina TJ, Wells RS, Singh J. Eco-toxicants: A growing global threat. In: Yamagiwa J, Karczmarski L, editors. Primates and cetaceans. Tokyo: Springer; 2014. p. 309-332. https://doi.org/10.1007/978-4-43154523-1_16

20. Landrigan PJ, Fuller R, Fisher S, Suk WA, Sly P, Chiles TC, et al. Pollution and children's health. Sci Total Environ. 2019;650(29):2389-2394. https://doi org/10.1016/j.scitotenv.2018.09.375

21. Schiedek D, Sundelin B, Readman JW, Macdonald RW. Interactions between climate change and contaminants. Mar Pollut Bull. 2007:54(12):1846-1856. https://doi.org/10.1016/j.marpolbul.2007.09.020

22. Linares C, Martinez GS, Kendrovski V, Diaz J. A new integrative perspective on early warning systems for health in the context of climate change. Environ Res 2020;187, Art. \#109623. https://doi.org/10.1016/j.envres.2020.109623

23. Arenas-Sánchez A, Rico A, Vighi M. Effects of water scarcity and chemical pollution in aquatic ecosystems: State of the art. Sci Total Environ. 2016;572:390-403. https://doi.org/10.1016/j.scitotenv.2016.07.211

24. Fang SC, Rodrigues EG, Christiani DC. Environmental health hazards in the tropics. In: Ryan ET, Hill DR, Solomon T, Aronson NE, Endy TP, editors. Hunter's tropical medicine and emerging infectious diseases. Elsevier; 2020. p. 200-208. https://doi.org/10.1016/B978-0-323-55512-8.00026-0

25. Myers N, Mittermeier RA, Mittermeier CG, da Fonseca GAB, KentJ. Biodiversity hotspots for conservation priorities. Nature. 2000;403(6772):853-858. https://doi.org/10.1038/35002501 
26. United Nations Department of Economic and Social Affairs, Statistic Division. Methodology [webpage on the Internet]. No date [cited 2021 Feb 15]. Available from: https://unstats.un.org/unsd/methodology/m49/

27. Mittermeier RA, Turner WR, Larsen FW, Brooks TM, Gascon C. Global biodiversity conservation: The critical role of hotspots. In: Zachos FE, Habel JC, editors. Biodiversity hotspots. Berlin: Springer; 2011. p. 3-22. https://doi. org/10.1007/978-3-642-20992-5_1

28. Kandie FJ, Krauss M, Beckers LM, Massei R, Fillinger U, Becker J, et al. Occurrence and risk assessment of organic micropollutants in freshwater systems within the Lake Victoria South Basin, Kenya. Sci Total Environ. 2020;714:1-13. https://doi.org/10.1016/j.scitotenv.2020.136748

29. Aremu JO. Conflicts in Africa: Meaning, causes, impact and solution. African Res Rev. 2010;4(4):549-560. https://doi.org/10.4314/afrrev.v4i4.69251

30. Kumie A, Kloos H. Occupational health and industrial pollution. In: Berhane $\mathrm{Y}$, Haile Mariam D, Kloos H, editors. The epidemiology and ecology of health and disease in Ethiopia. Addis Ababa: Shama Books; 2006. p. 171-195.

31. Jayaraj R, Megha P, Sreedev P. Organochlorine pesticides, their toxic effects on living organisms and their fate in the environment. Interdiscip Toxicol. 2016;9(3-4):90-100. https://doi.org/10.1515/intox-2016-0012

32. Brack W, Aissa SA, Backhaus T, Dulio V, Escher Bl, Faust M, et al. Effectbased methods are key. The European Collaborative Project SOLUTIONS recommends integrating effect-based methods for diagnosis and monitoring of water quality. Environ Sci Eur. 2019;31(19):1-6. https://doi.org/10.1186/ s12302-019-0192-2

33. Wu X, Cobbina SJ, Mao G, Xu H, Zhang Z, Yang L. A review of toxicity and mechanisms of individual and mixtures of heavy metals in the environment. Environ Sci Pollut Res. 2016;23:8244-8259. https://doi.org/10.1007/ s11356-016-6333-x

34. De Troyer N, Mereta ST, Goethals PL, Boets P. Water quality assessment of streams and wetlands in a fast growing East African city. Water. 2016;8(4), Art. \#123. https://doi.org/10.3390/w8040123

35. Mengistie E, Ambelu A, Van Gerven T, Smets I. Impact of tannery effluent on the self-purification capacity and biodiversity level of a river. Bull Environ Contam Toxicol. 2016:96(3):369-375. https://doi.org/10.1007/s00128016-1735-5

36. Desalegne SA. Macroinvertebrate-based bioassessment of rivers in Addis Ababa, Ethiopia. Afr J Ecol. 2018;56(2):262-271. https://doi.org/10.1111/ aje. 12444

37. Mereta ST, Ambelu A, Ermias A, Abdie Y, Moges M, Haddis A, et al. Effects of untreated industrial effluents on water quality and benthic macroinvertebrate assemblages of Lake Hawassa and its tributaries, Southern Ethiopia. Afr J Aquat Sci. 2020;45(3):285-295. https://doi.org/10.2989/16085914.2019. 1671166

38. Musonge PLS, Boets P, Lock K, Ambarita NMD, Forio MAE, Verschuren $D$, et al. Baseline assessment of benthic macroinvertebrate community structure and ecological water quality in Rwenzori rivers (Albertine rift valley, Uganda) using biotic-index tools. Limnologica. 2019;75:1-10. https://doi. org/10.1016/j.limno.2018.12.001

39. Musonge PLS, Boets P, Lock K, Ambarita MND, Forio MAE, Goethals PLM. Rwenzori score (RS): A benthic macroinvertebrate index for biomonitoring rivers and streams in the Rwenzori Region, Uganda. Sustainability. 2020;12(24):1-18. https://doi.org/10.3390/su122410473

40. Spirhanzlova P, Fini J-B, Demeneix B, Lardy-Fontan S, Vaslin-Reimann S, Lalere B, et al. Composition and endocrine effects of water collected in the Kibale National Park in Uganda. Environ Pollut. 2019;251:460-468. https:// doi.org/10.1016/j.envpol.2019.05.006

41. Badamasi I, Odong R, Masembe C. Implications of increasing pollution levels on commercially important fishes in Lake Victoria. J Great Lakes Res. 2019;45(6):1274-1289. https://doi.org/10.1016/j.jgl.2019.09.024

42. Focardi S, Corsi I, Mazzuoli S, Vignoli L, Loiselle SA, Focardi S. Integrating remote sensing approach with pollution monitoring tools for aquatic ecosystem risk assessment and management: A case study of Lake Victoria (Uganda). Environ Monit Assess. 2006:122:275-287. https://doi. org/10.1007/s10661-005-9180-7

43. Martins DJ. Differences in odonata abundance and diversity in pesticidefished, traditionally-fished and protected areas in Lake Victoria, Eastern Africa (Anisoptera). Odonatologica. 2009;38(3):261-265.
44. Polder A, Müller MB, Lyche JL, Mdegela RH, Nonga HE, Mabiki FP, et al. Levels and patterns of persistent organic pollutants (POPs) in tilapia (Oreochromis sp.) from four different lakes in Tanzania: Geographical differences and implications for human health. Sci Total Environ. 2014;488-489:252-260. https://doi.org/10.1016/j.scitotenv.2014.04.085

45. Campbell L, Verburg P, Dixon DG, Hecky RE. Mercury biomagnification in the food web of Lake Tanganyika (Tanzania, East Africa). Sci Total Environ. 2008;402(2-3):184-191. https://doi.org/10.1016/j.scitotenv.2008.04.017

46. Hanna DEL, Buck DG, Chapman LJ. Effects of habitat on mercury concentrations in fish: A case study of Nile perch (Lates niloticus) in Lake Nabugabo, Uganda. Ecotoxicology. 2016:25:178-191. https://doi. org/10.1007/s10646-015-1578-6

47. Ndaruga AM, Ndiritu GG, Gichuki NN, Wamicha WN. Impact of water quality on macroinvertebrate assemblages along a tropical stream in Kenya. Afr J Ecol. 2004;42(3):208-216. https://doi.org/10.1111/j.1365-2028.2004.00516.x

48. Masese FO, Muchiri M, Raburu PO. Macroinvertebrate assemblages as biological indicators of water quality in the Moiben River, Kenya. Afr J Aquat Sci. 2009;34(1):15-26. https://doi.org/10.2989/AJAS.2009.34.1.2.727

49. Minaya V, McClain E, Moog 0, Moog 0, Omengo F, Singer GA. Scale-dependent effects of rural activities on benthic macroinvertebrates and physico-chemical characteristics in headwater streams of the Mara River, Kenya. Ecol Indic. 2013;32:116-122. https://doi.org/10.1016/j.ecolind.2013.03.011

50. Abong'o DA, Wandiga S0, Jumba I0, Van den Brink PJ, Naziriwo BB, Modadi V0, et al. Occurrence, abundance and distribution of benthic macroinvertebrates in the Nyando River catchment, Kenya. Afr J Aquat Sci. 2015;40(4):373-392. https://doi.org/10.2989/16085914.2015.1113397

51. Alavaisha $E$, Lyon SW, Lindborg R. Assessment of water quality across irrigation schemes: A case study of wetland agriculture impacts in Kilombero Valley, Tanzania. Water. 2019;11(4):1-22. https://doi.org/10.3390/ w11040671

52. Groffen T, Rijnders J, Van Doorn L, Jorissen C, De Borger SM, Luttikhuis $\mathrm{DO}$, et al. Preliminary study on the distribution of metals and persistent organic pollutants (POPS), including perfluoroalkylated acids (PFAS), in the aquatic environment near Morogoro, Tanzania, and the potential health risks for humans. Environ Res. 2021;1921-11. https://doi.org/10.1016/j. envres.2020.110299

53. Mdegela RH, Braathen M, Mosha RD, Skaare JU, Sandvik M. Assessment of pollution in sewage ponds using biomarker responses in wild African sharptooth cattish (Clarias gariepinus) in Tanzania. Ecotoxicology. 2010;19:722-734. https://doi.org/10.1007/s10646-009-0449-4

54. Omwenga I, Kanja L, Nguta J, Mbaria J, Irungu P. Organochlorine pesticide residues in farmed fish in Machakos and Kiambu counties, Kenya. Cogent Environ Sci. 2016;2(1):1-9. https://doi.org/10.1080/23311843.2016.1153 215

55. Otieno PO, Lalah JO, Virani M. Carbofuran and its toxic metabolites provide forensic evidence for furadan exposure in vultures (Gyps africanus) in Kenya. Bull Environ Contam Toxicol. 2010;84(5):536-544. https://doi.org/10.1007/ s00128-010-9956-5

56. Otieno PO, Lalah JO, Virani M, Jodinko IO, Schramm KW. Carbofuran use and abuse in Kenya: Residues in soils, plants, water courses and the African white-backed vultures (Gyps africanus) found dead. Environmentalist. 2011;31(4):382-393. https://doi.org/10.1007/s10669-011-9350-9

57. Amusa C, Rothman J, Odongo S, Matovu H, Ssebugere P, Baranga D, et al. The endangered African great ape: Pesticide residues in soil and plants consumed by mountain gorillas (Gorilla beringei) in Bwindi Impenetrable National Park, East Africa. Sci Total Environ. 2021;758(1):1-11. https://doi. org/10.1016/j.scitotenv.2020.143692

58. Krief S, Berny P, Gumisiriza F, Gross R, Demeneix B, Fini JB, et al. Agricultural expansion as risk to endangered wildlife: Pesticide exposure in wild chimpanzees and baboons displaying facial dysplasia. Sci Total Environ. 2017;598:647-656. https://doi.org/10.1016/j.scitotenv.2017.04.113

59. Lacroux C, Guma N, Krief S. Facial dysplasia in wild forest olive baboons (Papio anubis) in Sebitoli, Kibale National Park, Uganda: Use of camera traps to detect health defects. J Med Primatol. 2019;48(3):143-153. https://doi. org/10.1111/jmp. 12408 
60. Wang SR, Steiniche T, Rothman JM, Wrangham RW, Chapman CA, Mutegeki $\mathrm{R}$, et al. Faeces are effective biological samples for measuring pesticides and flame retardants in primates. Environ Sci Technol. 2020;54(19):1201312023. https://doi.org/10.1021/acs.est.0c02500

61. Buhungu S, Sibomana C, Adjahouinou DC, Ntakimazi G, Bonou CA Montchowui E. Assessment of the ecological status of the Kinyankonge River (Burundi), using a Biotic Integrity Index of zooplankton (Bll-zooplankton). Afr J Aquat Sci. 2020;45(4):442-451. https://doi.org/10.2989/16085914.2020 .1753647

62. Gomes-Silva G, Cyubhairo E, Wronski T, Riesch R, Apio A, Plath M. Water pollution affects fish community structure and alters evolutionary trajectories of invasive guppies (Poecilia reticulata). Sci Total Environ. 2020;15(730):114. https://doi.org/10.1016/j.scitotenv.2020.138912

63. Syakalima M, Choongo K, Nakazato $\mathrm{Y}$, Onuma M, Sugimoto C, Tsubota T, et al. An investigation of heavy metal exposure and risks to wildlife in the Kafue Flats of Zambia. J Vet Med Sci. 2001;63(3):315-318. https://doi. org/10.1292/jvms.63.315

64. Syakalima M, Choongo K, Chilonda P, Ahmadu B, Mwase M, Onuma M, et al. Bioaccumulation of lead in wildlife dependent on the contaminated environment of the Kafue Flats. Bull Environ Contam Toxicol. 2001;67:438445. https://doi.org/10.1007/s001280143

65. Almli B, Mwase M, Sivertsen T, Musonda MM, Flåøyen A. Hepatic and renal concentrations of 10 trace elements in crocodiles (Crocodylus niloticus) in the Kafue and Luangwa rivers in Zambia. Sci Total Environ. 2005;337(13):75-82. https://doi.org/10.1016/j.scitotenv.2004.06.019

66. Flåøyen A, Polder A, Mwase M, Almli B, Musonda MM. Pesticide residues in adipose tissue from hippopotami (Hippopotamus amphibius L) living in and adjacent to the Luangwa River in Zambia. Onderstepoort J Vet Res. 2005;72(2):181-183. https://doi.org/10.4102/ojvr.v72i2.216

67. Nakayama SMM, Ikenaka Y, Hamada K, Muzandu K, Choongo K, Yabe J, et al. Accumulation and biological effects of metals in wild rats in mining areas of Zambia. Environ Monit Assess. 2013;185:4907-4918. https://doi. org/10.1007/s10661-012-2912-6

68. Nakayama SMM, Nakata H, Ikenaka Y, Yabe J, Oroszlany B, Yohannes YB, et al. One year exposure to $\mathrm{Cd}$ - and $\mathrm{Pb}$-contaminated soil causes metal accumulation and alteration of global DNA methylation in rats. Environ Pollut 2019;252:1267-1276. https://doi.org/10.1016/j.envpol.2019.05.038

69. Choongo KC, Syakalima MS, Mwase M. Coefficient of condition in relation to copper levels in muscle of serranochromis fish and sediment from the Kafue River, Zambia. Bull Environ Contam Toxicol. 2005;75:645-651. https://doi. org/10.1007/s00128-005-0801-1
70. Doya R, Nakayama SMM, Nakata H, Toyomaki H, Yabe J, Muzandu K, et al. Land use in habitats affects metal concentrations in wild lizards around a former lead mining site. Environ Sci Technol. 2020;54(22):14474-14481. https://doi.org/10.1021/acs.est.0c00150

71. Siziba N, Matshisela A, Mwedzi T, Bere T. Macroinvertebrate communities in riverine systems of buffer areas of protected wildland, rangeland and city areas: Implications for conservation of riverine systems on urbanising watersheds. Environ Sci Pollut Res. 2018;25(1):758-770. https://doi. org/10.1007/s11356-017-0487-z

72. Mwedzi T, Siziba N, Odume ON, Nyamazana E, Mabika I. Responses of macroinvertebrate community metrics to urban pollution in semi-arid catchments around the city of Bulawayo, Zimbabwe. 2020;46(4):583-592. https://doi.org/10.17159/wsa/2020.v46.i4.9071

73. Bere T, Dalu T, Mwedzi T. Detecting the impact of heavy metal contaminated sediment on benthic macroinvertebrate communities in tropical streams Sci Total Environ. 2016;1(572):147-156. http://dx.doi.org/10.1016/j. scitotenv.2016.07.204

74. Ganzhorn JU, Lowry II PP, Schatz GE, Sommer S. The biodiversity of Madagascar: One of the world's hottest hotspots on its way out. Oryx. 2001;35(4):346-348. https://doi.org/10.1046/j.1365-3008.2001.00201.x

75. International Union for Conservation of Nature (IUCN). The IUCN red list of threatened species - Madagascar [webpage on the Internet]. No date [cited 2021 Feb 15]. Available from: https://www.iucnredlist.org/search?landRegio ns $=$ MG\&searchType $=$ species

76. Rainwater TR, Sauther ML, Rainwater KAE, Mills RE, Cuozzo FP, Zhang B, et al. Assessment of organochlorine pesticides and metals in ring-tailed lemurs (Lemur catta) at Beza Mahafaly Special Reserve, Madagascar. Am J Primatol. 2009;71:998-1010. https://doi.org/10.1002/ajp.20742

77. Junge RE, Barrett MA, Yoder AD. Effects of anthropogenic disturbance on indri (Indri indri) health in Madagascar. Am J Primatol. 2011;73:632-642. https://doi.org/10.1002/ajp.20938

78. Tingle CCD, Rother JA, Dewhurst CF, Lauer S, King WJ. Fipronil: Environmental fate, ecotoxicology, and human health concerns. Rev Environ Contam Toxicol. 2003;176:1-66. https://doi.org/10.1007/978-1-4899-7283-5_1

79. Musoke D, Ndejjo R, Atusingwize E, Halage AA. The role of environmental health in One Health: A Uganda perspective. One Health. 2016;2:157-160. https://doi-org/10.1016/j.onehlt.2016.10.003

80. Madagascar Health and Pollution Action Plan-Accelerating the implementation of actions to reduce pollution-related illness. Global Alliance on Health and Pollution; 2018. Available from: https://gahp.net/hpap-madagascar/ 